\title{
Study on the Hymenoptera parasitoid associated with Lepidoptera larvae in reforestation and agrosilvopastoral systems at Fazenda Canchim (Embrapa Pecuária Sudeste) São Carlos, SP, Brazil
}

\author{
A. G. Pereira ${ }^{*}$, R. B. Silva ${ }^{b}$, M. M. Dias ${ }^{a}$ and A. M. Penteado-Dias ${ }^{a}$ \\ aPrograma de Pós-graduação em Ecologia e Recursos Naturais, Departamento de Ecologia e Biologia Evolutiva - DEBE, \\ Universidade Federal de São Carlos - UFSCar, CP 676, CEP 13565-905, São Carlos, SP, Brazil \\ ${ }^{\text {b} D e p a r t a m e n t o ~ d e ~ E n g e n h a r i a ~ A m b i e n t a l ~ e ~ S a n i t a ́ r i a ~-~ D E A S, ~ F a c u l d a d e s ~ S a n t o ~ A g o s t i n h o ~ d e ~ S e t e ~ L a g o a s ~-~ F a s a s e t e, ~}$ \\ CEP 35701-281, Sete Lagoas, MG, Brazil \\ *e-mail: alinegpbio@yahoo.com.br
}

Received: November 13, 2013 - Accepted: July 4, 2014 - Distributed: November 30, 2015

\begin{abstract}
The aim of this study was to characterize the local fauna of Hymenoptera parasitoids associated with Lepidoptera larvae in areas of reforestation and agrosilvopastoral systems at Fazenda Canchim (Embrapa Pecuária Sudeste, São Carlos, SP, Brazil). Lepidoptera larvae collected with entomological umbrella were kept in the laboratory until emergence of adults or their parasitoids. From those collected in the agrosilvopastoral system, emerged 267 specimens of hymenopteran parasitoids belonging to 16 genera: Braconidae, Agathidinae (Alabagrus), Braconinae (Bracon), Microgastrinae (Cotesia, Diolcogaster, Glyptapanteles, Pholetesor and Protapanteles), Orgilinae (Orgilus); Ichneumonidae, Campopleginae (Casinaria, Charops and Microcharops); Chalcididae, Chalcidinae (Brachymeria and Conura); Eulophidae, Entedoninae (Horismenus), Eulophinae (Elachertus and Euplectrus). From the Lepidoptera larvae collected in the reforestation, emerged 68 specimens of hymenopteran parasitoids, belonging to 8 genera: Chalcididae, Chalcidinae (Conura); Ichneumonidae, Pimplinae (Neotheronia), Campopleginae (Charops and Microcharops) and Braconidae, Microgastrinae (Apanteles, Diolcogaster, Distatrix, Glyptapanteles and Protapanteles). The results of this study suggest the occurrence of a wide variety of Hymenoptera parasitoids in the studied environments.
\end{abstract}

Keywords: biodiversity, parasitoid, taxonomy.

\section{Estudo dos Hymenoptera parasitoides associados a larvas de Lepidoptera em reflorestamento e sistema agrossilvipastoril na Fazenda Canchim (Embrapa Pecuária Sudeste), São Carlos, SP, Brasil}

\section{Resumo}

O objetivo deste trabalho foi caracterizar a fauna local de Hymenoptera parasitoides associados a larvas de Lepidoptera em área de reflorestamento (corredor ecológico) e de sistema agrossilvipastoril na Fazenda Canchim (Embrapa Pecuária Sudeste, São Carlos, SP, Brasil). Larvas de Lepidoptera coletadas com guarda-chuva entomológico foram mantidas em laboratório até a emergência dos adultos ou de seus parasitoides. Daquelas coletadas no sistema agrossilvipastoril emergiram 267 espécimes de himenópteros parasitoides, pertencentes a 16 gêneros: Braconidae, Agathidinae (Alabagrus), Braconinae (Bracon), Microgastrinae (Cotesia, Diolcogaster, Glyptapanteles, Pholetesor e Protapanteles), Orgilinae (Orgilus); Ichneumonidae, Campopleginae (Casinaria, Charops e Microcharops); Chalcididae, Chalcidinae (Brachymeria e Conura); Eulophidae, Entedoninae (Horismenus), Eulophinae (Elachertus e Euplectrus). No reflorestamento emergiram 68 espécimes de himenópteros parasitoides, pertencentes a 8 gêneros: Chalcididae, Chalcidinae (Conura); Ichneumonidae; Pimplinae (Neotheronia), Campopleginae (Charops e Microcharops); Braconidae, Microgastrinae (Apanteles, Diolcogaster, Glyptapanteles e Protapanteles). Os resultados obtidos sugerem que os ambientes estudados abrigam grande diversidade de Hymenoptera parasitoides.

Palavras-chave: biodiversidade, parasitoide, taxonomia.

\section{Introduction}

The Hymenoptera are a key group to establish priorities for conservation, because they are sensitive to changes in land use and habitat quality and fulfill important ecological

roles. Within this group, the parasitoids control the population of other insects that interfere in trophic chains of most agroecosystems (Perioto et al., 2004). 
Many Lepidoptera are distinguished as pests that affect agricultural production, which stimulated researches in the areas of taxonomy and biology in order to use Hymenoptera parasitoids for biological control of these insects (Souza et al., 2006). This information becomes relevant when seeking recovery environmental indicators because the Hymenoptera have high diversity and can be easily sampled by a variety of methods. In an attempt to recover ecologically degraded landscapes and reduce the impacts of agricultural activities, new combinations of landscapes have emerged: agroforestry system and reforestation areas are recurrent examples of these new approaches. The composition of Hymenoptera parasitoids in these environments is poorly studied, especially regarding food plants of their host (Fernandes et al., 2010). Biodiversity inventories report the spatial distribution of biological elements (Kremen et al., 1993; Samways, 1993) and allow the characterization of the community that can be used in proposals for monitoring and conservation of environments (Longino and Colwell, 1997).

The aim of this study was to characterize the Hymenoptera parasitoids associated with Lepidoptera larvae collected from plants in area of reforestation and agrosilvopastoral system.

\section{Material and Methods}

The study was conducted at Fazenda Canchim, Embrapa Pecuária Sudeste, São Carlos, SP, Brazil (21 ${ }^{\circ} 55^{\prime} \mathrm{S}$ and $47^{\circ} 48^{\prime}$ W) from May 2010 to June 2012.

The Fazenda Canchim has approximately 2,538 hectares, of which 1,491 with pastures and experimental plots and 1,047 of permanent preservation areas and legal reserves. Climate is classified as a CWA-Awa (Köppen), with two distinct seasons: dry from April to September and the wet season from October to March. The average maximum and minimum temperatures are 26.8 and $15.6{ }^{\circ} \mathrm{C}$, respectively. The annual relative humidity is $75.6 \%$ and the average altitude $850 \mathrm{~m}$. The predominant soil is a typic dystrophic red latosol (Primavesi et al., 2008).

The reforestation system (R) has six hectares, with 51 different plant species. The agrosilvopastoral system (AS) has 12 hectares, including pastures and six species of native forest plants.

Samplings of larvae were made every two weeks from May 2010 to July 2012, using an entomological umbrella. Larvae of Lepidoptera collected were kept in the laboratory on host plants in individual plastic containers. The adults of the parasitoid Hymenoptera, as well as their pupae, the head capsules and debris of host larvae were preserved in $70 \%$ ethanol. The main literature sources used for the identification of Braconidae, Chalcididae and Ichneumonidae were Wharton et al. (1997), Gibson (1997) and Gauld (1991), respectively.

The Lepidoptera were identified by one of the authors of this work (M.M.D.). Parasitized larvae of Lepidoptera were identified using the head capsule and external morphology, besides comparison with photographic records.
The specimens of Lepidoptera and Hymenoptera were deposited at the Coleção Taxonômica do Departamento de Ecologia e Biologia Evolutiva, Universidade Federal de São Carlos, (DCBU). The plant samples were deposited at the Herbarium of Departamento de Botânica, Universidade Federal de São Carlos (HUFSCAR).

\section{Results}

During the sampling period, 129 Lepidoptera larvae were collected in reforestation (R), 14 of which were parasitized (10.8\%). In agrosilvopastoral system (AS) 403 larvae of Lepidoptera were collected and 33 were parasitized (8.2\%) (Table 1). Sampled plant species are at Table 2.

Species of Ichneumonidae (Campopleginae), Chalcididae (Chalcidinae) and Braconidae (Microgastrinae) occurred in the two sampling sites. The Braconidae (Agathidinae, Braconinae and Orgilinae) and Eulophidae (Entedoninae and Eulophinae) only occurred in the agrosilvopastoral system, while Ichneumonidae (Pimplinae) occurred only in reforestation (Table 2).

The Microgastrinae accounted for $64.58 \%$ of the total individuals captured in the two environments, followed by Entedoninae (9.23\%), Chalcidinae (7.74\%), Braconinae (7.14\%), Eulophinae (5.65\%), Campopleginae (4.17\%), Agathidinae $(0.60 \%)$, Orgilinae $(0.60 \%)$ and Pimplinae (0.30\%) (Table 2).

Considering the two systems, the most abundant species were gregarious, especially representatives of the subfamilies Chalcidinae, Microgastrinae, Entedoninae and Eulophinae (Table 2).

In reforestation were collected 65 specimens of four genera of Braconidae, six specimens of three genera of Ichneumonidae and seven specimens of three genera of Chalcididae (Table 2).

In the agrosilvopastoral system 189 specimens of Braconidae were collected of eight genera, nine specimens of Ichneumonidae of one genus, 50 specimens of Eulophidae of three genera and 19 specimens of Chalcididae of two genera (Table 2).

\section{Discussion}

The highest number of larvae was observed in the agrosilvopastoral system, however the percentage of parasitism was lower than that obtained in reforestation. The Microgastrinae were the most abundant in the two environments, however, presenting the largest number of

Table 1. Results of sampling of larvae collected in reforestation and agrosilvopastoral systems of Fazenda Canchim (Embrapa Pecuária Sudeste), São Carlos, SP, Brazil from May 2010 to July 2012.

\begin{tabular}{cccc}
\hline Environment & $\begin{array}{c}\text { Lepidoptera } \\
\text { larvae collected }\end{array}$ & \multicolumn{2}{c}{$\begin{array}{c}\text { Parasitized } \\
\text { larvae }\end{array}$} \\
\cline { 3 - 4 } & $(\mathbf{N})$ & $\mathbf{( N )}$ & $\mathbf{( \% )}$ \\
\hline Reforestation & 129 & 14 & 10.8 \\
Agrosilvopastoral & 403 & 33 & 8.2 \\
\hline
\end{tabular}


Table 2. Number of specimens and relative frequency of Hymenoptera obtained from Lepidoptera larvae collected in reforestation (R) and agrosilvopastoral systems (AS) at Fazenda Canchim (Embrapa Pecuária Sudeste), São Carlos, SP, Brazil, from May 2010 to July 2012.

\begin{tabular}{|c|c|c|c|c|c|}
\hline $\begin{array}{c}\text { Parasitoid } \\
\text { (Hymenoptera) }\end{array}$ & $\begin{array}{c}\text { Host } \\
\text { (Lepidoptera) }\end{array}$ & $\mathbf{R}$ & AS & Host plant & $\begin{array}{c}\text { Relative } \\
\text { frequency }(\%)\end{array}$ \\
\hline \multicolumn{6}{|l|}{ BRACONIDAE } \\
\hline \multicolumn{6}{|l|}{ Agathidinae } \\
\hline Alabagrus sp.* & $\begin{array}{l}\text { Olethreutinae } \\
\text { Tortricidae }\end{array}$ & 0 & 2 & $\begin{array}{l}\text { Guazuma ulmifolia } \\
\text { Lam. } \\
\text { Malvaceae }\end{array}$ & 0.60 \\
\hline \multicolumn{6}{|l|}{ Braconinae } \\
\hline Bracon sp.** & $\begin{array}{l}\text { Euglyphis sp. } \\
\text { Lasiocampidae }\end{array}$ & 0 & 24 & $\begin{array}{l}\text { Croton floribundus } \\
\text { Spreng. } \\
\text { Euphorbiaceae }\end{array}$ & 7.14 \\
\hline \multicolumn{6}{|l|}{ Microgastrinae } \\
\hline Apanteles sp. ${ }^{*}$ & $\begin{array}{l}\text { Lygropia unicoloralis } \\
\text { (Guenée,1854) } \\
\text { Crambidae }\end{array}$ & 1 & 0 & $\begin{array}{l}\text { Aegiphila } \\
\text { sellowiana } \\
\text { Cham. } \\
\text { Lamiaceae }\end{array}$ & 0.30 \\
\hline Cotesia $\mathrm{sp} 1 .^{* *}$ & $\begin{array}{l}\text { Memphis appias } \\
\text { (Hübner, [1825]) } \\
\text { Nymphalidae }\end{array}$ & 0 & 57 & Croton floribundus & 16.96 \\
\hline Diolcogaster sp1.* & Noctuidae & 0 & 2 & Croton floribundus & 0.60 \\
\hline Diolcogaster sp2." & Noctuidae & 1 & 0 & $\begin{array}{l}\text { Machaerium sp. } \\
\text { Fabaceae }\end{array}$ & 0.30 \\
\hline Glyptapanteles sp1.** & $\begin{array}{l}\text { Bagisara paulensis } \\
\text { (Schaus, 1898) } \\
\text { Noctuidae }\end{array}$ & 0 & 1 & Croton floribundus & 0.30 \\
\hline Glyptapanteles sp2.** & $\begin{array}{l}\text { Thyrinteina arnobia } \\
\text { (Stoll,1782) } \\
\text { Geometridae }\end{array}$ & 10 & 29 & Croton floribundus & 11.61 \\
\hline Pholetesor sp.** & $\begin{array}{l}\text { Saturniidae } \\
\text { Hemileucinae }\end{array}$ & 0 & 26 & Croton floribundus & 7.74 \\
\hline Protapanteles sp.** & $\begin{array}{l}\text { Glena sp. } \\
\text { Geometridae }\end{array}$ & 43 & 46 & $\begin{array}{l}\text { Trichilia hirta L. } \\
\text { Meliaceae }\end{array}$ & 26.49 \\
\hline \multicolumn{6}{|l|}{ Orgilinae } \\
\hline Orgilus sp.* & $\begin{array}{l}\text { Iridopsis sapulena } \\
\text { (Schaus, 1897) } \\
\text { Geometridae }\end{array}$ & 0 & 2 & Croton floribundus & 0.60 \\
\hline \multicolumn{6}{|l|}{ ICHNEUMONIDAE } \\
\hline \multicolumn{6}{|l|}{ Campopleginae } \\
\hline Casinaria sp1.* & Noctuidae & 0 & 2 & Guazuma ulmifolia & 0.60 \\
\hline Casinaria sp2.* & Lepidoptera & 0 & 1 & $\begin{array}{l}\text { Anadenanthera } \\
\text { colubrina (Vell.) } \\
\text { Brenan } \\
\text { Fabaceae }\end{array}$ & 0.30 \\
\hline Casinaria sp3.* & $\begin{array}{l}\text { Glena sp. } \\
\text { Geometridae }\end{array}$ & 0 & 1 & $\begin{array}{l}\text { Anadenanthera } \\
\text { colubrina }\end{array}$ & 0.30 \\
\hline Casinaria sp4.* & $\begin{array}{l}\text { Apatelodes sp. } \\
\text { Apatelodidae }\end{array}$ & 0 & 2 & Croton floribundus & 0.60 \\
\hline Casinaria sp5.* & $\begin{array}{l}\text { Bertholdia } \text { sp. } \\
\text { Noctuidae }\end{array}$ & 0 & 1 & Croton floribundus & 0.30 \\
\hline Charops sp.* & Geometridae & 1 & 0 & Machaerium sp. & 0.30 \\
\hline
\end{tabular}

"Solitary Habit. ${ }^{* *}$ Gregarious Habit. 
Table 2. Continued...

\begin{tabular}{|c|c|c|c|c|c|}
\hline $\begin{array}{c}\text { Parasitoid } \\
\text { (Hymenoptera) }\end{array}$ & $\begin{array}{c}\text { Host } \\
\text { (Lepidoptera) }\end{array}$ & $\mathbf{R}$ & AS & Host plant & $\begin{array}{c}\text { Relative } \\
\text { frequency }(\%)\end{array}$ \\
\hline Microcharops sp1.* & Euglyphis sp. & 3 & 2 & $\begin{array}{l}\text { Nectandra } \\
\text { megapotamica } \\
\text { (Spreng.) Mez } \\
\text { Lauraceae }\end{array}$ & 1.49 \\
\hline Microcharops sp2.* & Euglyphis sp. & 1 & 0 & $\begin{array}{l}\text { Vernonia rubriramea } \\
\text { Mart. ex DC. } \\
\text { Asteraceae }\end{array}$ & 0.30 \\
\hline \multicolumn{6}{|l|}{ Pimplinae } \\
\hline Neotheronia sp.* & $\begin{array}{l}\text { Brachurapteryx } \\
\text { breviaria } \\
\text { (Hübner, [1831]) } \\
\text { Geometridae }\end{array}$ & & 0 & Croton floribundus & 0.30 \\
\hline \multicolumn{6}{|l|}{ CHALCIDIDAE } \\
\hline \multicolumn{6}{|l|}{ Chalcidinae } \\
\hline Brachymeria sp.** & $\begin{array}{l}\text { Brachurapteryx } \\
\text { breviaria }\end{array}$ & & 1 & $\begin{array}{l}\text { Croton } \\
\text { floribundus }\end{array}$ & 0.30 \\
\hline Conura sp1.** & $\begin{array}{l}\text { Brachurapteryx } \\
\text { breviaria }\end{array}$ & & 17 & $\begin{array}{l}\text { Croton } \\
\text { floribundus }\end{array}$ & 7.44 \\
\hline Conura sp2." & $\begin{array}{l}\text { Brachurapteryx } \\
\text { breviaria }\end{array}$ & & 1 & $\begin{array}{l}\text { Croton } \\
\text { floribundus }\end{array}$ & 0.30 \\
\hline \multicolumn{6}{|l|}{ EULOPHIDAE } \\
\hline $\begin{array}{l}\text { Horismenus sp.** } \\
\text { Eulophinae }\end{array}$ & Memphis appias & 0 & 31 & Croton floribundus & 9.23 \\
\hline Elachertus sp.** & Bagisara paulensis & 0 & 3 & Croton floribundus & 0.89 \\
\hline Euplectrus sp.** & Bagisara paulensis & 0 & 16 & Croton floribundus & 4.76 \\
\hline Total & & 68 & 267 & & 100.00 \\
\hline
\end{tabular}

"Solitary Habit. ${ }^{* *}$ Gregarious Habit.

genera in the agrosilvopastoral system; this subfamily is cosmopolitan, highly diversified, comprising koinobiont endoparasitoids, solitary or gregarious on larvae of Lepidoptera (Mason, 1981; Whitfield et al., 2009). The other subfamilies of Braconidae occurred to a lesser extent, and included a variety of genera, mainly endoparasitoids of Lepidoptera larvae.

Specimens of Alabagrus sp. (Braconidae, Agathidinae) were found parasitizing larvae of Olethreutinae in agrosilvopastoral system. A similar study accomplished in the same area of this work observed Apanteles sp. on Eupithecia sp. in the agrosilvopastoral system (C. S. Souza, personal comm.), while in this work we have found this parasitoid on Lygropia unicoloralis in reforestation. According to Yu et al. (2012), no association of Apanteles spp. is known with L. unicoloralis, therefore this is the first report of the occurrence of this parasitoid on this host.

Other study in the same area using Malaise trap, has reported the occurrence of Cotesia sp. in all the studied environments (C. S. Souza, personal comm.) contrasting with the data found in this survey, where Cotesia sp. was found only in the agrosilvopastoral system. Salgado-Neto
(2013) presented aspects of the biology of Cotesia alius (Muesebeck, 1958) on Opsiphanes invirae amplificatus Stichel, 1904 (Nymphalidae) in Brazil.

The present study observed the presence of Diocolgaster spp. in the two cultivation systems; the specimens emerged from larvae of Noctuidae (Lepidoptera). According to Yu et al. (2012), species of Diolcogaster was already observed in association with 90 items within 14 families of Lepidoptera, most species of Noctuidae. Tavares et al. (2012) studied the biological association of Diolcogaster sp. and Agaraea minuta (Schaus, 1892) (Arctiidae) on Costus spp. (Costaceae) in Brazil.

Glyptapanteles species were reported to the same area, associated with Euphitecia sp. (Geometridae), in the systems agrosilvopastoral and reforestation (C. S. Souza, personal comm.). This work, observed Glyptapanteles sp. in the same areas, but on Bagisara paulensis and Thyrinteina arnobia. There are no reports regarding association of Glyptapanteles spp. with these hosts (Yu et al., 2012) being this the first occurrence of this parasitoid on these Lepidoptera. Glyptapanteles species are solitary or gregarious parasitoids of macrolepidopterous larvae 
(Mason, 1981), with a cosmopolitan distribution, very common and diversified (Whitfield et al., 2009). Braga et al. (2001) reported parasitism of Glyptapanteles sp. on Eois tegularia (Guenée, [1858]) (Geometridae); other study (L.B.R. Fernandes, personal comm.) has reported seven species of Glyptapanteles, one gregarious and six solitary associated with Glena sp., Brachurapteryx breviaria, Semaeopus sp. and Hymenomima sp. (Geometridae). Kenis et al. (2005) reported the association of Glyptapanteles vitripennis (Curtis, 1830) on young larvae of Eupithecia lariciata (Freyer, 1841) (Geometridae); Whitfield et al. (2009) recorded 94 occurrences of Glyptapanteles spp. on Lepidoptera of Ecuador, associated with species of the families Apatelodidae, Arctiidae, Geometridae, Limacodidae, Noctuidae, Nymphalidae, Pieridae, Pyralidae and Saturniidae. They reported that Glyptapanteles spp. associated to Limacodidae are unusual, but the other registered associations are typical of the genus in other regions.

There are several reports of the genus Pholetesor associated with Saturniidae (Wharton et al., 1997; Whitfield et al., 2009) in different areas and we have found this parasitoid on Saturniidae, Hemileucinae.

In this study, Protapanteles sp. was found in both areas on Glena sp. (Geometridae). It is a genus whose species are endoparasitoids of Lepidoptera larvae and species of Geometridae are the main hosts (Yu et al., 2012).

Marconato et al. (2008) reported parasitism of Protapanteles sp. on Hymenomima amberia (Schaus, 1901) and Macaria regulata (Fabricius, 1775) (Geometridae). Penteado-Dias et al. (2011) reported, the first occurrence in Brazil of Protapanteles (Protapanteles) enephes (Nixon, 1965) (Braconidae), associated with the larva of Fountainea ryphea phidile (Geyer, 1837) (Nymphalidae) in two deciduous forest fragments in São Carlos, SP.

There were reports of Orgilus sp. parasitizing larvae of Iridopsis sapulena (Schaus, 1897) (Geometridae); species of this family have been reported as hosts to Orgilinae in different areas (Braet and van Achterberg, 2001).

We have found Casinaria spp. parasitizing species of the families Geometridae (Glena sp.), Apatelodidae (Apatelodes sp.), Noctuidae (Bertholdia sp.). According to Yu et al., (2012) there were no reports about the genus Casinaria on these Lepidoptera, being the first occurrences of those associations. Charops sp. was found on larvae of Geometridae, only in reforestation area.

There are several reports of species of Microcharops associated to Euglyphis sp. (Gauld, 1991; Yu et al., 2012) and we found the same in this study.

The genus Horismenus Walker, 1843 was cited by Riley et al. (1894), Ashmead (1904) and Crawford (1911) as an important natural enemy hyperparasitoid on Cotesia alius (Muesebeck, 1958) (Braconidae, Microgastrinae) (Salgado- Neto and Di Mare, 2010; Salgado-Neto, 2013). This genus is predominantly a New World group, with its main distribution in the Neotropical region. The 400 described species are parasitoids or hyperparasitoids on a variety of hosts, most commonly on larvae of Coleoptera, Diptera and Lepidoptera (Hansson, 2009). Records includes both solitary or gregarious species, specialist or generalist parasitoids, and as far as is known all are endoparasitoids and presumably koinobionts (Hansson et al., 2011).

Elachertus sp. and Euplectrus sp. parasitizing larvae of Bagisara paulensis (Noctuidae) were found in the agrosilvopastoral system; other species of this family of Lepidoptera were reported as hosts of Eulophinae by other authors (Zhu and Huang, 2003).

The diversity of Hymenoptera can be increased by the greater availability of food resources for parasitoids, as hosts for their immature stages and increased diversity of the surrounding vegetation (Altieri and Letourneau, 1982; Altieri et al., 1984; Campos and Cure, 1993). The results suggest that the studied environments present a great diversity of Hymenoptera parasitoids, due to a greater availability of food resources for them and also for their hosts. Thus, reforestation practices and mixed systems of environment utilization should be encouraged. New studies on the interactions of plant-host-parasitoid may assist the monitoring of the distribution of the species involved in landscape structure.

\section{Acknowledgements}

To "Coordenação de Aperfeiçoamento de Pessoal de Nível Superior (CAPES)", "Conselho Nacional de Desenvolvimento Científico e Tecnológico (CNPq)", "Fundação de Amparo à Pesquisa do Estado de São Paulo (FAPESP)" and "Instituto Nacional de Ciência e Tecnologia dos Hymenoptera Parasitoides da Região Sudeste Brasileira (INCT/Hympar-Sudeste)", for the support; to Maria Luiza Franceschi Nicodemo, for the authorization for collections at Fazenda Canchim, Embrapa Pecuária Sudeste (São Carlos, SP, Brazil) and informations about the area of the present study; to Maria Inês Salgueiro Lima, for the identification of plant species, to Airton Santo Soares, for assistance in the collections of material; to Ana Paula da Silva Loffredo and Marco Aurélio Bortoni, for help in identifying the Ichneumonidae and Braconidae, respectively.

\section{References}

ALTIERI, M.A. and LETOURNEAU, D.K., 1982. Vegetation management and biological control in agroecosystems. Crop Protection (Guildford, Surrey), vol. 1, no. 4, pp. 405-430. http:// dx.doi.org/10.1016/0261-2194(82)90023-0.

ALTIERI, M.A., LETOURNEAU, D.K. and RISCH, S.J., 1984. Vegetation diversity and insect pest outbreaks. CRC Critical Reviews in Plant Sciences, vol. 2, no. 2, pp. 131-169. http:// dx.doi.org/10.1080/07352688409382193.

ASHMEAD, W.H., 1904. Classification of the chalcid flies or the superfamily Chalcidoidea, with descriptions of new species in the Carnegie Museum. Publications of the Carnegie Museum, vol. 1, pp. 255-551.

BRAET, Y. and VAN ACHTERBERG, C., 2001. Notes on the genera Exasticolus van Achterberg (Homolobinae) and Orgilus Haliday (Orgilinae) (Hymenoptera: Braconidae), with the 
description of three new species from French Guiana. Zoölogische Mededeelingen, vol. 75, pp. 89-102.

BRAGA, S.M.P., DIAS, M.M. and PENTEADO-DIAS, A.M., 2001. Aspectos bionômicos de Eois tegularia (Guenée) e Eois glauculata (Walker) (Lepidoptera, Geometridae, Larentiinae) e seus parasitoides. Revista Brasileira de Zoologia, vol. 18, no. 3, pp. 837-840. http://dx.doi.org/10.1590/S0101-81752001000300019.

CAMPOS, W.G. and CURE, J.R., 1993. Lagartas, seus danos e parasitóides associados em reflorestamento de Eucalyptus cloënsiana no Vale do Rio Doce (MG). Revista Brasileira de Entomologia, vol. 37, no. 1, pp. 1-13.

CRAWFORD, J.C., 1911. Descriptions of new Hymenoptera. Proceedings of the United States National Museum, vol. 40, no. 1830, pp. 446-447. http://dx.doi.org/10.5479/si.00963801.401830.439 .

FERNANDES, L.B.R., DIAS FILHO, M.M., FERNANDES, M.A. and PENTEADO-DIAS, A.M., 2010. Ichneumonidae (Hymenoptera) parasitoids of Lepidoptera caterpillars feeding on Croton floribundus Spreng Euphorbiaceae). Revista Brasileira de Entomologia, vol. 54, no. 2, pp. 263-269. http://dx.doi.org/10.1590/ S0085-56262010000200009.

GAULD, I.D., 1991. The Ichneumonidae of Costa Rica. Memoirs of the American Entomological Institute, vol. 47, pp. 1-589.

GIBSON, G.A.P., 1997. Morphology and terminology. In: G.A.P. GIBSON, J.T. HUBER and J.B. WOOLEY, eds. Annotated keys to genera of Neartic Chalcidoidea (Hymenoptera). Ottawa: NRC Research Press, pp. 16-44.

HANSSON, C., 2009. Eulophidae of Costa Rica 3: genus Horismenus. Memoirs of the American Entomological Institute, vol. 82, pp. 1-916.

HANSSON, C., LACHAUD, J.P. and PEREZ-LACHAUD, G., 2011. Entedoninae wasps (Hymenoptera, Chalcidoidea, Eulophidae) associated with ants (Hymenoptera, Formicidae) in tropical America, with new species and notes on their biology. ZooKeys, vol. 134, pp. 65-82. PMid:22140342.

KENIS, M., HERZ, K., WEST, R.J. and SHAW, M.R., 2005. Parasitoid assemblages reared from geometrid defoliators (Lepidoptera: Geometridae) of larch and fir in the alps. Agricultural and Forest Entomology, vol. 7, no. 4, pp. 307-318. http://dx.doi. org/10.1111/j.1461-9555.2005.00277.x.

KREMEN, C., COLWELL, R.K., ERWIN, T.L., MURPHY, D.D., NOSS, R.F. and SANJAYAN, M.A., 1993. Terrestrial arthropod assemblages, their use in conservation planning. Conservation Biology, vol. 7, no. 4, pp. 796-808. http://dx.doi.org/10.1046/j.15231739.1993.740796.x.

LONGINO, J.T. and COLWELL, R.K., 1997. Biodiversity assessment using structured inventory: capturing the ant fauna of a tropical rain forest. Ecological Applications, vol. 7, no. 4, pp. 1263-1277. http://dx.doi.org/10.1890/1051-0761(1997)007[1263:BA USIC]2.0.CO;2.

MARCONATO, G., DIAS, M.M. and PENTEADO-DIAS, A.M., 2008. Larvas de Geometridae (Lepidoptera) e seus parasitóides, associadas a Erythroxylum microphyllum St.-Hilaire (Erythroxylaceae). Revista Brasileira de Entomologia, vol. 52, no. 2, pp. 296-299. http://dx.doi.org/10.1590/S0085-56262008000200010.

MASON, W.R.M., 1981. The polyphyletic nature of Apanteles Foerster (Hymenoptera: Braconidae): a phylogeny and reclassification of Microgastrinae. Memoirs of the Entomological Society of
Canada, vol. 115, no. 115, pp. 1-147. http://dx.doi.org/10.4039/ entm113115fv.

PENTEADO-DIAS, A.M., FERNANDES, L.B.R., IEMMA, L.G.R. and DIAS, M.M., 2011. First occurrence of Protapanteles (Protapanteles) enephes (Nixon, 1965) (Hymenoptera, Braconidae, Microgastrinae) in Brazil and new biological data. Brazilian Journal of Biology $=$ Revista Brasileira de Biologia, vol. 71, no. 3, pp. 735-738. http://dx.doi.org/10.1590/S1519-69842011000400019. PMid:21881798.

PERIOTO, N.W., LARA, R.I.R., SELEGATTO, A. and LUCIANO, E.S., 2004. Himenópteros parasitóides (Insecta: Hymenoptera) coletados em cultura de café Coffea arabica L. (Rubiaceae) em Ribeirão Preto, SP, Brasil. Arquivos do Instituto Biologico, vol. 71, pp. 41-44.

PRIMAVESI, O., VINHOLIS, M.M.B., NICODEMO, M.L.F., CORDEIRO, C.A., ESCRIVANI, L.P., ANTONIO, F.J.A., SOUZA, G.B. and NOGUEIRA, A.R.A., REGITANO, L.C.A. and BERNARDI, A.C.C., 2008 [viewed 1 August 2012]. Ações de gestão ambiental: o caso da Embrapa Pecuária Sudeste [online]. Available from: http://www.cnpma.embrapa.br/boaspraticas/index. php3?id $=344 \& \mathrm{it}=\mathrm{pb} \&$ func $=$ unid

RILEY, C.V., ASHMEAD, W.H. and HOWARD, L.O., 1894. Report upon the parasitic hymenoptera of the island of St. Vincent. Zoological Journal of the Linnean Society, vol. 25, no. 1, pp. 56-254. http://dx.doi.org/10.1111/j.1096-3642.1894.tb00982.x.

SALGADO-NETO, G. and DI MARE, R.A., 2010. Hiperparasitóides em Cotesia alius (Mues.) (Hymenoptera: Braconidae) no estado do Rio Grande do Sul, Brasil. Magistra, vol. 22, pp. 210-212.

SALGADO-NETO, G., 2013. Aspects of the biology of Cotesia alius (Muesebeck,1958) (Hymenoptera: Braconidae: Microgastrinae) on Opsiphanes invirae amplificatus Stichel (Lepidoptera: Nymphalidae) in Rio Grande do Sul, Brazil. Estudos de Biologia, vol. 35, no. 440, pp. 34-41. http://dx.doi.org/10.7213/estud.biol.7854.

SAMWAYS, M.J., 1993. Insects in biodiversity conservation: some perspectives and directives. Biodiversity and Conservation, vol. 2, no. 3, pp. 258-282. http://dx.doi.org/10.1007/BF00056672.

SOUZA, L., BRAGA, S.M.P. and CAMPOS, M.J.O., 2006. Himenópteros parasitóides (Insecta, Hymenoptera) coletados em área agrícola de Rio Claro, SP, Brasil. Arquivos do Instituto Biologico, vol. 73, pp. 465-469.

TAVARES, W.S., SALGADO-NETO, G., LEGASPI, J.C.L., RAMALHO, F.D.S., SERRÃO, J.E. and ZANUNCIO, J.C., 2012. The biological and ecologiacal consequences of Diolcogaster sp. (Hymenoptera: Braconidae) parasitizing Agaraea minuta (Lepidoptera: Arctiidae) and the effects on two Costus (Costaceae) plant species in Brazil. The Florida Entomologist, vol. 95, no. 4, pp. 966-970. http://dx.doi.org/10.1653/024.095.0422.

WHARTON, R.A., MARSH, P.M. and SHARKEY, M.J., ed. 1997. Manual of the new world genera of the family Braconidae (Hymenoptera). Washington, DC: International Society of Hymenopterists. 439 p. Special Publication of the International Society of Hymenopterist, no. 1.

WHITFIELD, J.B., RODRIGUEZ, J.J. and MASONICK, P.K., 2009. Reared Microgastrine wasps (Hymenoptera: Braconidae) from Yanayacu Biological Station and environs (Napo Province, Ecuador): diversity and host specialization. Journal of Insect Science, vol. 9, no. 31, pp. 1-22. http://dx.doi.org/10.1673/031.009.3101. PMid:19613864. 
YU, D.S., van ACHTERBERG, C. and HORSTMANN, K., 2012. World Ichneumonoidea: taxonomy, biology, morphology and distribution [DVD/CD]. Vancouver: Taxapad.
ZHU, C.-D. and HUANG, D.-W., 2003. A study of the genus Euplectrus Westwood (Hymenoptera: Eulophidae). Zoological Studies (Taipei, Taiwan), vol. 42, pp. 140-164. 